\title{
IDENTIFIKASI LETAK DAN JENIS RUANG TERBUKA HIJAU DI KAWASAN PERMUKIMAN PERKOTAAN
}

\author{
Nada Alifia \\ (Mahasiswa) Program Studi Arsitektur, Universitas Tanjungpura, Indonesia \\ nadaalifia06@gmail.com
}

\section{Yudi Purnomo}

Program Studi Arsitektur, Universitas Tanjungpura, Indonesia

\begin{abstract}
Abstrak
Perkembangan penduduk dalam sebuah kawasan permukiman sejalan dengan meningkatnya pembangunan permukiman. Pembangunan yang dilakukan seringkali tidak di imbangi oleh pemenuhan dan penyediaan ruang terbuka bagi penduduk. Kawasan RW 01 Kelurahan Paal Lima, Kecamatan Pontianak Barat, Kota Pontianak merupakan sebuah kawasan permukiman perkotaan yang memiliki potensi ruang terbuka yang dapat dimanfaatkan, namun belum secara spesifik difungsikan sebagai ruang terbuka hijau.

Penelitian ini dilakukan dilakukan dengan metode kualitatif dan kuantitatif.. Pada metode kuantitatif akan ditekankan pada analisis data yang berupa perhitungan kebutuhan Ruang Terbuka Hijau berdasarkan jumlah penduduk, luas wilayah lingkungan Rukun Warga. Metode kualitatif yang didukung oleh metode AHP (Analytical Hierarchy Process) difungsikan untuk mengetahui kriteria Ruang Terbuka Hijau yang dibutuhkan oleh warga dan mengetahui kepuasan warga terhadap hadirnya Ruang Terbuka yang ada pada saat ini.

Hasil akhir dari penelitian ini adalah menemukan titik-titik/letak-letak potensi ruang terbuka hijau (RTH) yang pilih berdasarkan faktor RTH dekat dengan fasilitas umum (fasilitas keagamaan), RTH dekat/tepian anak sungai, RTH berada ditepian jalan utama, RTH memanfaatkan lahan fasilitas umum. Kualitas yang dibutuhkan adalah terlayaninya penduduk, untuk kenyamanan, keindahan, kelestarian serta kesehatan bagi masyarakat. Fungsi yang dibutuhkan adalah sarana aktivitas sosial bagi anak-anak, remaja, dewasa dan manula dan jenis RTH yang dibutuhkan adalah jenis Taman Lingkungan dan lapangan olahraga. Hasil akhir penelitian ini adalah menemukan titik potensi RTH dan kebutuhan kualitas, fungsi, dan jenis RTH yang dibutuhkan masyarakat.
\end{abstract}

Kata Kunci: Ruang Terbuka Hijau, Permukiman, Perkotaan

\begin{abstract}
Increasing number of people in a residential area is in line with the increase in settlement construction. Development of urban areas is not balanced by fulfillment and provision of open space. The research location is an urban settlement area that has the potential of open space that can be utilized, but not specifically functioned as a green open space.

This research was conducted with qualitative and quantitative methods. In quantitative methods will be emphasized on the analysis of data in the form of green open space requirement calculations based on population and neighborhood area. Qualitative methods are supported by AHP (Analytical Hierarchy Process) to determine the criteria of green open
\end{abstract}


space needed by the citizens and to determine citizen satisfaction towards open space that is available at this time.

The final result of this research is to find locations that have the potential as a green open space based on the needs of the community. The chosen location of which is distantly related to public facilities (eg religious facilities), near or on the river bank, located around the main street and in public facilities land. The quality of green open space is needed is to provide a sense of comfort, beauty, sustainability and public health. Functions and types of green open space which is expected by the public are parks and sports fields as a means of social activities for children, adolescents, adults and the elderly.

Keywords: Green Open Space, Settlements, Cities

\section{Pendahuluan}

Kawasan perkotaan adalah wilayah yang mempunyai kegiatan utama bukan pertanian dengan susunan fungsi kawasan sebagai tempat permukiman perkotaan, pemusatan dan distribusi pelayanan jasa pemerintahan, pelayanan sosial, dan kegiatan ekonomi (Direktorat Jenderal Penataan Ruang, 2008). Sebagai pusat perkembangan, kawasan perkotaan akan menarik dan meningkatkan rasio kependudukan di suatu wilayah. Pertumbuhan penduduk yang meningkat akan berdampak kembali kepada peningkatan pembangunan untuk permukiman di kawasan perkotaan. Perkembangan pembangunan kota saat ini menunjukkan kecenderungan terjadinya aktivitas pembangunan yang tidak seimbang (Rushayati, dkk, 2011).

Pembangunan yang tidak seimbang mengakibatkan penggunaan lahan yang tidak diimbangi dengan pemenuhan dan penyediaan ruang. Penggunaan lahan sebagai ruang terbangun (solid) salah satunya disebabkan oleh tingginya nilai ekonomis lahan perkotaan. Sedangkan lahan atau tanah merupakan sumber daya yang terbatas, sementara pertumbuhan penduduk dan kebutuhan akan perumahan dan permukiman di perkotaan terus meningkat. Hal ini lah yang menyebabkan rendahnya pemanfaatan lahan perkotaan sebagai ruang terbuka (hijau).

Ruang terbuka hijau kota memiliki peran yang cukup penting bagi kehidupan perkotaan, salah satunya adalah sebagai paru-paru kawasan. Banyak peranan yang dapat di berikan oleh ketersediaan dan keberadaan ruang terbuka hijau, seperti sumber Departemen Dalam Negeri Republik Indonesia mengeluarkan Instruksi Menteri Dalam Negeri Nomor 14 Tahun 1988 tentang Penataan Ruang Terbuka Hijau (RTH) di Wilayah Perkotaan yang memberikan peranan RTH bagi pengembangan kota adalah sebagai areal perlindungan berlangsungnya fungsi ekosistem dan penyangga kehidupan; sebagai sarana untuk menciptakan kebersihan, kesehatan, keserasian dan kehidupan lingkungan; sebagai sarana rekreasi; sebagai pengaman lingkungan hidup perkotaan terhadap berbagai macam pencemaran baik di darat, perairan maupun udara; sebagai sarana penelitian danpendidikan serta penyuiuhan bagi ma syarakat untuk membentuk kesadaran Iingkungan; sebagai tempat perlindungan plasma nuftah; sebagai sarana untuk mempengaruhi dan memperbaildiklim mikro; dan sebagai pengatur tata air.

Lokasi penelitian yang berada di RW 01, Kelurahan Paal Lima, Kecamatan Pontianak Barat, Kota Pontianak merupakan sebuah kawasan permukiman perkotaan dengan peningkatan jumlah penduduk yang tinggi dan memiliki potensi ruang terbuka (hijau) untuk di kembangkan. Banyak potensi ruang terbuka yang dapat dimanfaatkan, namun belum secara spesifik difungsikan sebagai ruang terbuka. Sebagai kawasan permukiman yang sedang berkembang dengan tingkat pembangunan dan pembukaan lahan untuk perumahan- 
perumahan yang cepat, kawasan ini tidak mengolah dengan baik ketersediaan dan keberadaan Ruang Terbuka Hijau yang ada. Hal ini mengakibatkan tidak terpenuhinya Ruang Terbuka Hijau secara aktif pada kawasan ini.

Keberadaan ruang terbuka hijau (RTH) diatur dalam Undang Undang No. 26 Tahun 2007 tentang Penataan Ruang yaitu disebutkan bahwa jumlah RTH di setiap kota harus sebesar 30 (tiga puluh) persen dari luas kota tersebut. Proporsi kebutuhan ruang terbuka hijau tersebut diatur untuk memenuhi fungsi utama sebagai fungsi ekolofis dan fungsi tambahan sebagai fungsi sosial dan budaya, ekonomi, serta fungsi estetika (Direktorat Jenderal Penataan Ruang, 2008). Berdasarkan ketentuan dan kebijakan baiknya sebuah permukiman yang berada pada kawasan perkotaan memenuhi kententuan di atas.

Pemenuhan dan keberadaan ruang terbuka hijau secara langsung dan tidak langsung akan mempengaruhi kualitas lingkungan dan kehidupan di kawasan permukiman perkotaan. Penelitian ini dilakukan dengan tujuan untuk menganalisa potensi jenis dan letak ruang terbuka hijau di kawasan permukiman perkotaan, khususnya di RW 01, Kelurahan Paal Lima, Kecamatan Pontianak Barat, Kota Pontianak. Pemetaan Potensi Ruang Terbuka Hijau akan dapat memberikan rekomendasi perletakan Ruang Terbuka Hijau berdasarkan jumlah penduduk dan potensi wilayah perencanaan Ruang Terbuka Hijau.

\section{Kajian Literatur \\ Ruang Terbuka Hijau}

Ruang Terbuka hijau adalah area memanjang/jalur dan/atau mengelompok, ynag penggunaannya lebih bersifat terbuka, tempat tumbuh tanaman, baik yang tumbuh secara alamiah (Direktorat Jenderal Penataan Ruang, 2008). Dalam Peraturan Menteri Dalam Negeri No.1 Tahun 2007 tentang Penataan Ruang Terbuka Hijau Kawasan Perkotaan, ruang terbuka hijau kawasan perkotaan adalah bagian dari ruang terbuka suatu kawasan perkotaan yang diisi oleh tumbuhan dan tanaman guna mendukung manfaat ekologi, sosial, budaya, ekonomi dan estetika.

Berdasarkan dalam Peraturan Menteri Dalam Negeri No. 1 tahun 2007 Tentang Penataan Ruang Terbuka Hijau Kawasan Perkotaan, manfaat RTH adalah sebagai berikut:

a) Sarana untuk mencerminkan identitas daerah.

b) Sarana penelitian, pendidikan, dan penyuluhan.

c) Sarana rekreasi aktif dan pasif serta interaksi sosial.

d) Meningkatkan nilai ekonomi lahan perkotaan.

e) Menumbuhkan rasa bangga dan meningkatkan prestise daerah.

f) Sarana aktivitas sosial bagi anak-anak, remaja, dewasa, dan manula.

g) Sarana ruang evakuasi untuk keadaan darurat.

h) Memperbaiki iklim mikro; danMeningkatkan cadangan oksigen di perkotaan

Dalam Peraturan Menteri Pekerjaan Umum nomor: 05/PRT/M/2008 tentang Pedoman Penyediaan dan Pemanfaatan Ruang Terbuka Hijau di Kawasan Perkotaan di jelaskan jenis dan sifat dari ruang terbuka hijau (RTH). Secara fisik RTH dapat dibedakan menjadi RTH alami berupa habitat liar alami, kawasan lindung dan taman-taman nasional serta RTH non alami atau binaan seperti taman, lapangan olahraga, pemakaman atau jalur-jaur hijau jalan. Dilihat dari fungsi RTH dapat berfungsi ekologis, sosial budaya, estetika, dan ekonomi. Secara struktur ruang, RTH dapat mengikuti pola ekologis (mengelompok, memanjang, tersebar), maupun pola planologis yang mengikuti hirarki dan struktur ruang perkotaan. Dari segi kepemilikan, RTH dibedakan ke dalam RTH publik dan RTH privat.

Berdasarkan ketentuan mengenai jenis-jenis RTHKP dijelaskan pada Permendagri No. 1 Tahun 2007 Tentang Penataan Ruang Terbuka Hijau Kawasan Perkotaan meliputi 23 jenis. Tetapi, RTH publik di Kota Tangerang memiliki 18 jenis yaitu sebagai berikut : 
a) Taman Lingkungan;

b) Taman Kecamatan

c) RTH taman kota;

d) Hutan Kota

e) RTH jalur jalan hijau;

f) RTH ruang pejalan kaki;

g) Jalur hijau sempadan rel kereta api;

h) Jalur hijau pada jaringan tegangan tinggi;

i) RTH sempadan sungai;

j) RTH sumber air baku/mata air;

k) RTH pemakaman;

1) RTH lapangan olahraga

m) Perkebunan

n) Pertanian lahan basah

Peraturan Departemen Pekerjaan Umum Tahun 2008 tentang Pedoman Penyediaan dan Pemanfaatan Ruang Terbuka Hijau di Kawasan Perkotaan menjelaskan klasifikasi Ruang Terbuka Hijau terbagi menjadi berdasarkan bobot dan tingkat kuaslitasnya. Berdasarkan bobot kealamiannya, bentuk RTH dapat diklasifikasi menjadi:

a) Bentuk RTH alami (habitat liar/alami, kawasan lindung)

b) Bentuk RTH non alami atau RTH binaan (pertanian kota, pertamanan kota, lapangan olah raga, pemakaman

Berdasarkan sifat dan karakter ekologisnya diklasifikasi menjadi:

a) Bentuk RTH kawasan (areal)

b) bentuk RTH jalur (koridor)

Berdasarkan penggunaan lahan atau kawasan fungsionalnya diklasifikasi menjadi:

a) RTH kawasan perdagangan

b) RTH kawasan perindustrian

c) RTH kawasan permukiman

d) RTH kawasan pertanian

e) RTH kawasan-kawasan khusus, seperti pemakaman, olah raga, alamiah

Secara kualitas, RTH perlu dibangun dan dikembangkan untuk memenuhi beberapa kebutuhan dasar penghuninya. Faktor-faktor pertimbangan itu mencakup pertimbangan (Budi Santoso, 2012):

a) Fisik atau dasar eksistensi lingkungan dengan membuat bentukbentuk geografis sesuai geotopograsinya

b) Sosial, untuk medorong penghuninya bersosialisasi

c) Ekonomi, untuk memberi peluang pengembangkan sumber produk yang bisa dijual (misal : bahan makanan berupa : bunga, buah, dedaunan/sayur mayur, bahkan untuk dipanen umbi dan atau akarnya

d) Budaya, sebagai ruang untuk mengekspresikan seni-budaya masyarakat

e) Kebutuhan akan terlayaninya hak-hak manusia (penduduk) untuk mendapatkan lingkungan yang aman (termasuk dari segi pentingnya kesehatan), nyaman, indah dan lestari yaitu fungsional dan estetis.

Secara umum penataan ruang ditujukan untuk menghasilkan suatu perencanaan tata ruang yang kita inginkan dimasa yang akan datang. Rencanatersebut lalu diwujudkan dalam bentuk pemanfaatan ruang yang sesuai dengan rencana yang ditetapkan. Pada dasarnya perencanaan tata ruang perkotaan dimulai dengan mengidentifikasi kawasan-kawasan yang secara alami harus diselamatkan (kawasan lindung) untuk menjamin kelestarian fungsi 
lingkungan, dan kawasan-kawasan yang secara alami rentan erhadap bencana(prone to natural hazards) seperti gempa, longsor, banjir maupun bencana alam lainnya.

Ada dua manfaat Ruang Terbuka Hijau (RTH) pada kawasan perkotaan yaitu (Direktorat Jenderal Penataan Ruang, 2008) :

a) Manfaat langsung (dalam pengertian cepat dan bersifat tangible), yaitu membentuk keindahan dan kenyamanan (teduh, segar, sejuk) dan mendapatkan bahan-bahan untuk dijual (kayu, daun, bunga, buah).

b) Manfaat tidak langsung (berjangka panjang dan bersifat intangible), yaitupembersih udara yang sangat efektif, pemeliharaan akan kelangsungan persediaan air tanah, pelestarian fungsi lingkungan beserta segala isi flora dan fauna yang ada (konservasi hayati atau keanekaragaman hayati).

\section{Kebutuhan Ruang Terbuka Hijau Berdasarkan Jumlah Penduduk}

Secara hirarkis dari yang terendah, skala pelayanan kegiatan fungsional suatu kota dapat dimulai dari skala lingkungan, yaitu RT, RW dan kelurahan, pada skala kawasan terdapat skala kecamatan sampai dengan skala tertinggi yaitu kota. Pada skala RW (Lihat Tabel 1) kebutuhan yang harus terpenuhi adalah 1250 meter dalam Laus minimal/unit nya 0,5 meter dengan loaksi di pusat kegiatan RW.

Tabel 1. Penyediaan RTH berdasarkan Jumlah Penduduk

\begin{tabular}{|c|c|c|c|c|c|}
\hline No & $\begin{array}{c}\text { Unit } \\
\text { Lingkunan }\end{array}$ & Tipe RTH & $\begin{array}{c}\text { Luas } \\
\text { Minimal/ } \\
\text { Unit (m2) }\end{array}$ & $\begin{array}{c}\text { Luas } \\
\text { Minimal/k } \\
\text { apita }(\mathrm{m} 2)\end{array}$ & Lokasi \\
\hline 1 & 250 jiwa & Taman RT & 250 & 1,0 & di tengah Lingkungan RT \\
\hline 2 & 2500 jiwa & Taman RW & 1250 & 0,5 & di pusat kegiatan RW \\
\hline 3 & 30.000 jiwa & Taman Kelurahan & 9000 & 0,3 & $\begin{array}{l}\text { dikelompokan dengan } \\
\text { sekolah/pusat kelurahan }\end{array}$ \\
\hline \multirow[t]{2}{*}{4} & \multirow[t]{2}{*}{120.000 jiwa } & Taman Kecamatan & 24000 & 0,2 & $\begin{array}{l}\text { dikelompokan dengan } \\
\text { sekolah/pusat kecamatan }\end{array}$ \\
\hline & & Pemakaman & disesuaikan & 1,2 & tersebar \\
\hline \multirow{3}{*}{5} & \multirow{3}{*}{480.000 jiwa } & Taman Kota & 144000 & 0,3 & dipusat wilayah/kota \\
\hline & & Hutan Kota & disesuaikan & 4,0 & $\begin{array}{l}\text { didalam/kawasan } \\
\text { pinggiran }\end{array}$ \\
\hline & & $\begin{array}{l}\text { untuk fungsi-fungsi } \\
\text { tertentu }\end{array}$ & disesuaikan & 12,5 & $\begin{array}{l}\text { disesuaikan degan } \\
\text { kebutuhan }\end{array}$ \\
\hline
\end{tabular}

Sumber: Direktorat Jenderal Penataan Ruang, 2008

\section{Kebutuhan Ruang Terbuka Hijau Berdasarkan Luas Wilayah}

Berdasarkan Peraturan Menteri Pekerjaan Umum No 05/PRT/M/2008 Penyediaan RTH berdasarkan luas wilayah di perkotaan adalah sebagai berikut:

a) Ruang terbuka hijau di perkotaan terdiri dari RTH Publik dan RTH privat.

b) Proporsi RTH pada wilayah perkotaan adalah sebesar minimal $30 \%$ yang terdiri dari $20 \%$ ruang terbuka hijau publik dan $10 \%$ terdiri dari ruang terbuka hijau privat;

c) Apabila luas RTH baik publik maupun privat di kota yang bersangkutan telah memiliki total luas lebih besar dari peraturan atau perundangan yang berlaku, maka proporsi tersebut harus tetap dipertahankan keberadaannya. 
Proporsi 30\% merupakan ukuran minimal untuk menjamin keseimbangan ekosistem kota, baik keseimbangan sistem hidrologi dan keseimbangan mikroklimat, maupun sistem ekologis lain yang dapat meningkatkan ketersediaan udara bersih yang diperlukan masyarakat, serta sekaligus dapat meningkatkan nilai estetika kota. Target luas sebesar 30\% dari luas wilayah kota dapat dicapai secara bertahap.

Menurut Peraturan Menteri Nomor 5 Tahun 2008 Ruang Terbuka Hijau (RTH) Kawasan Perkotaan adalah sebagai berikut : Ruang Kota terdiri dari ruang terbangun dan ruang terbuka. Ruang terbangun terdiri dari hunian adalah $40 \%$ dengan KDB adalah $80 \%$ dan non hunian adalah $20 \%$ dengan KDB 90\%. Ruang Terbuka HIjau (RTH) untuk hunian adalah $8 \%$ dan RTH non hunian $2 \%$ sehingga RTH privat adalah $10 \%$. Untuk ruang terbuka terdiri dari taman adalah 12,5\% dengan KDB 0\%, jalan adalah $20 \%$ dan lainnya 7,5\% dengan KDB adalah $80 \%$. Ruang terbuka hijau untuk taman $12,5 \%$, untuk jalan adalah $6 \%$ dan ruang terbuka hijau untuk lainnya $1,5 \%$ sehingga Ruang terbuka hijau publik.

\section{Metode Penelitian}

Penelitian ini dilakukan dilakukan dengan metode kualitatif dan kuantitatif.. Pada metode kuantitatif akan ditekankan pada analisis data yang berupa perhitungan kebutuhan Ruang Terbuka Hijau berdasarkan jumlah penduduk, luas wilayah lingkungan Rukun Warga. Metode kualitatif yang didukung oleh metode AHP (Analytical Hierarchy Process) difungsikan untuk mengetahui kriteria Ruang Terbuka Hijau yang dibutuhkan oleh warga lingkungan Rukun Warga dan mengetahui kepuasan warga terhadap hadirnya Ruang Terbuka yang ada pada saat ini.

Variabel penelitian di susun berdasarkan kajian literatur yang telah diuraikan di atas serta diarahkan untuk menjawab tujuan penelitian. Ada tiga kelompok indikator yang ditetapkan, yaitu luas ruang terbuka hijau, perletakan ruang terbuka hijau, dan jenis ruang terbuka hijau. Tabel 2 di bawah ini menjelaskan variable berdasarkan capaian indikator penelitian yang akan dicapai.

Tabel 2. Variebel Penelitian

\begin{tabular}{|c|c|c|c|}
\hline No & Indikator & Variabel & Definisi Operasional \\
\hline \multirow{3}{*}{1} & \multirow{3}{*}{$\begin{array}{l}\text { Luas Ruang } \\
\text { Terbuka Hijau }\end{array}$} & Jumlah Penduduk & $\begin{array}{l}\text { Penentuan Luas dengan standar } \\
\text { pemenuhan RTH pada kawasan } \\
\text { lingkngan RW }\end{array}$ \\
\hline & & Luas Wilayah & $\begin{array}{l}\text { Presentase Luasan berdasarkan } \\
\text { keentuan penyediaan }\end{array}$ \\
\hline & & Penyediaan Oksigen per-orang & $\begin{array}{l}\text { Kebutuhan Oksigen dalam kawasan } \\
\text { penelitian }\end{array}$ \\
\hline \multirow{2}{*}{2} & \multirow{2}{*}{$\begin{array}{l}\text { Perletakkan Ruang } \\
\text { Terbuka Hijau }\end{array}$} & Jarak dari pusat permukiman & $\begin{array}{l}\text { Jarak dari pusat permukiman sebagai } \\
\text { tujuan menentukan radius ketercapaian } \\
\text { akses }\end{array}$ \\
\hline & & $\begin{array}{l}\text { Tinjauan Peraturan dan } \\
\text { Kebijakan Pemerintah Kota }\end{array}$ & $\begin{array}{l}\text { Menyesuaikan dengan peruntukan yang } \\
\text { telah ditentukan dalam rencana tata } \\
\text { ruang }\end{array}$ \\
\hline \multirow[t]{2}{*}{3} & \multirow{2}{*}{$\begin{array}{l}\text { Jenis Ruang } \\
\text { Terbuka Hijau }\end{array}$} & Fungsi RTH & $\begin{array}{l}\text { Mengetahui kebutuhan RTH pada locus } \\
\text { berdasarkan pengamatan masyarakat }\end{array}$ \\
\hline & & Klasifikasi RTH & $\begin{array}{l}\text { Mengetahui model RTH yang } \\
\text { dibutuhkan }\end{array}$ \\
\hline
\end{tabular}

Sumber: Analisa, 2016 
Metode pengambilan sampel adalah dengan sampel nonprobabilitias yaitu sampel tidak diberikan kesempatan yang sama bagi setiap populasi untuk dipilih menjadi sampel. Dalam menentukan jumlah sampel peneliti menentukan untuk menggunakan Nomogram Harry King dalam (Ida Bagos Mantra, 2012). Dari gambar diatas dapat disebutkan bahwa jumlah populasi 2146 orang, tingkat kepercayaan yang dikehendaki adalah $80 \%$ dan tingkat error $15 \%$, maka jumlah sampel yang diambil adalah :

$$
\begin{aligned}
& \mathrm{n}=2146 \times(3 \%) \times 0.780 \\
& \mathrm{n}=50,2 \sim 50 \text { orang }
\end{aligned}
$$

\section{Hasil dan Pembahasan}

Berdasarkan gambar 1, kawasan penelitian adalah di RW 01 kelurahan Paal Lima. Kecamatan Pontianak Barat, Kota Pontianak. Sebagian wilayah penelitian menurut Rencana Tata Ruang Wilayah Kota Pontianak termasuk dalam kawasan pelestarian alam. Kawasan penelitian memerlukan penempatan Ruang Terbuka Hijau yang dapat memenuhi kebutuhan masyarakat secara aktif dan memenuhi standar kebutuhan Ruang Terbuka Hijau berdasarkan jumlah penduduk dan luas wilayah. Pemilihan pembagian wilayah berdasarkan RW di kelurahan Paal Lima di bagi menjadi 8 RT yang menjadi fokus penelitian. Pembagian ini di peruntukan agar pengamatan dan analisa dapat dilakukan secara merata dan analisa potensi yang dilakukan lebih rinci.

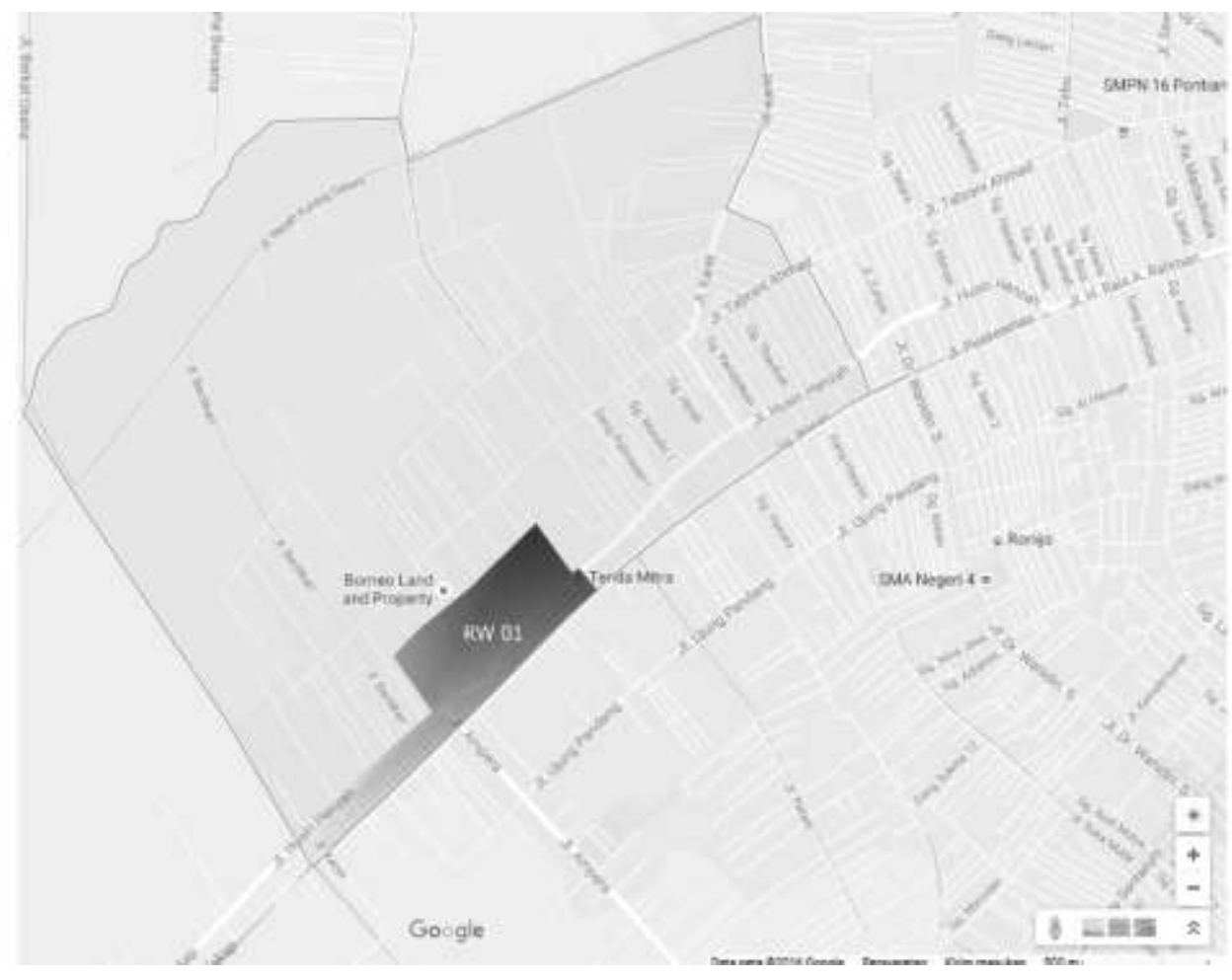

Gambar 1. Lokasi Penelitian

Sumber: Google Map dengan Modifikasi dan analisis berdasarkan Keterangan Kelurahan, 2017 


\section{Analisa Kebutuhan Ruang Terbuka Hijau}

Kebutuhan ruang terbuka hijau dilakukan melalui proses analisis kebutuhan masyarakat RW 01 Kelurahan Paal Lima terhadap jenis, fungsi, dan kualitas ruang terbuka hijau. Proses analisa diperoleh berdasarkan sampel yang sudah ditetapkan, dengan menggunakan Nomogram Harry King, yaitu 50 jiwa terhadap populasi RW yang berjumlah 2.146 jiwa.

\section{A. Ketersediaan Ruang Terbuka Hijau pada Kondisi Eksisting}

Berdasarkan hasil wawancara dan kuesioner terhadap kondisi eksisting ruang terbuka hijau di RW 01 Kelurahan Paal Lima, didapatkan hasil bahwa ketersediaan ruang terbuka hijau di RW 01 hanya 4\% populasi yang menjawab bahwa ada ruang terbuka hijau yang bisa dimanfaatkan pada lingkngan RW 01. Sedangkan 96\% populasi menjawab tidak adanya ruang terbuka hijau untuk lingkungan RW 01. Hal ini menjelaskan bahwa di RW 01 memang tidak adanya Ruang Terbuka Hijau yang dapat mendukung kehidupan masyarakat ataupun ruang terbuka hijau yang mampu meningkatkan nilai oksigen, estetika maupun kenyamanan iklim yang ada. Sebanyak 98\% persen responden menyatakan bahwa dibutuhkan ruang terbuka hijau yang layak di lingkungan RW 01 karena hal ini meninjau pentingnya pemenuhan kebutuhan Ruang Terbuka Hijau dan dampak-dampak positif lainnya untuk lingkungan, sedangkan ada $2 \%$ populasi yang menyatakan bahwa tidak butuhnya Ruang Terbuka Hijau pada Lingkungan RW 01. Sehingga dapat disimpulkan bahwa RW 01 belum memiliki Ruang Terbuka Hijau dan RW 01 membutuhkan Ruang Terbuka Hijau yang mampu mendukung segala kebutuhan dan kenyamanan masyarakat.

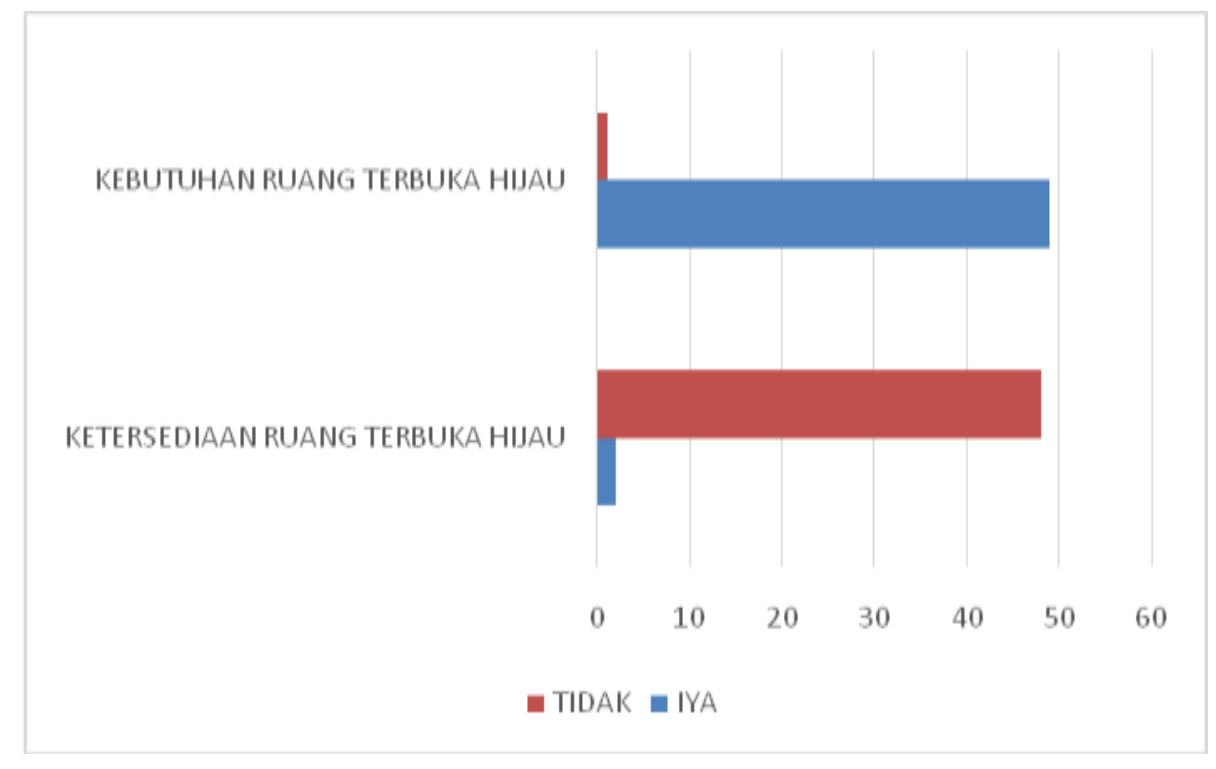

Gambar 2. Ketersediaan Ruang Terbuka Hijau pada Kondisi Eksisting RW 01 Sumber: Analisis, 2017

\section{B. Kepuasan Terhadap Ruang Terbuka Hijau}

Masyarakat RW 01 Kelurahan Paal Lima menyatakan bahwa tidak atau belum ada ruang terbuka hijau yang berfungsi untuk masyarakat hal ini di respon oleh $96 \%$ populasi sedangkan terdapat $4 \%$ populasi yang menyatakan bahwa ada Ruang Terbuka Hijau yang berfungsi untuk masyarakat. Dari $4 \%$ populasi yang menyatakan ada ruang terbuka hijau di lingkungan RW 01 menambahkan bahwa masyarakat sangat tidak puas terhadap Ruang Terbuka Hijau yang ada. Meskipun sudah ada Ruang Terbuka Hijau 
bagi $4 \%$ populasi namun fungsi, jenis dan kualitasnya masih belum sesuai dengan kebutuhan masyaraka. Sebanyak $98 \%$ populasi mengharapkan adanya Ruang Terbuka Hijau yang sesuai dengan kebutuhan, hal ini diharapkan karena masyarakat memang membutuhkan adanya ruang terbuka hijau yang layak untuk lingkungan $\mathrm{Rw} 01$. Terdapat $2 \%$ populasi yang menyatakan bahwa tidak mengharapkan adanya Ruang Terbuka Hijau untuk lingkungan RW 01. Maka dapat disimpulkan bahwa belum adanya ruang terbuka hijau yang ada dan berfungsi untuk menunjang kehidupan masyarakat dan masyarakat RW 01 mengharapkan adanya ruang terbuka hijau yang sesuai dengan kebutuhan masyarakat.

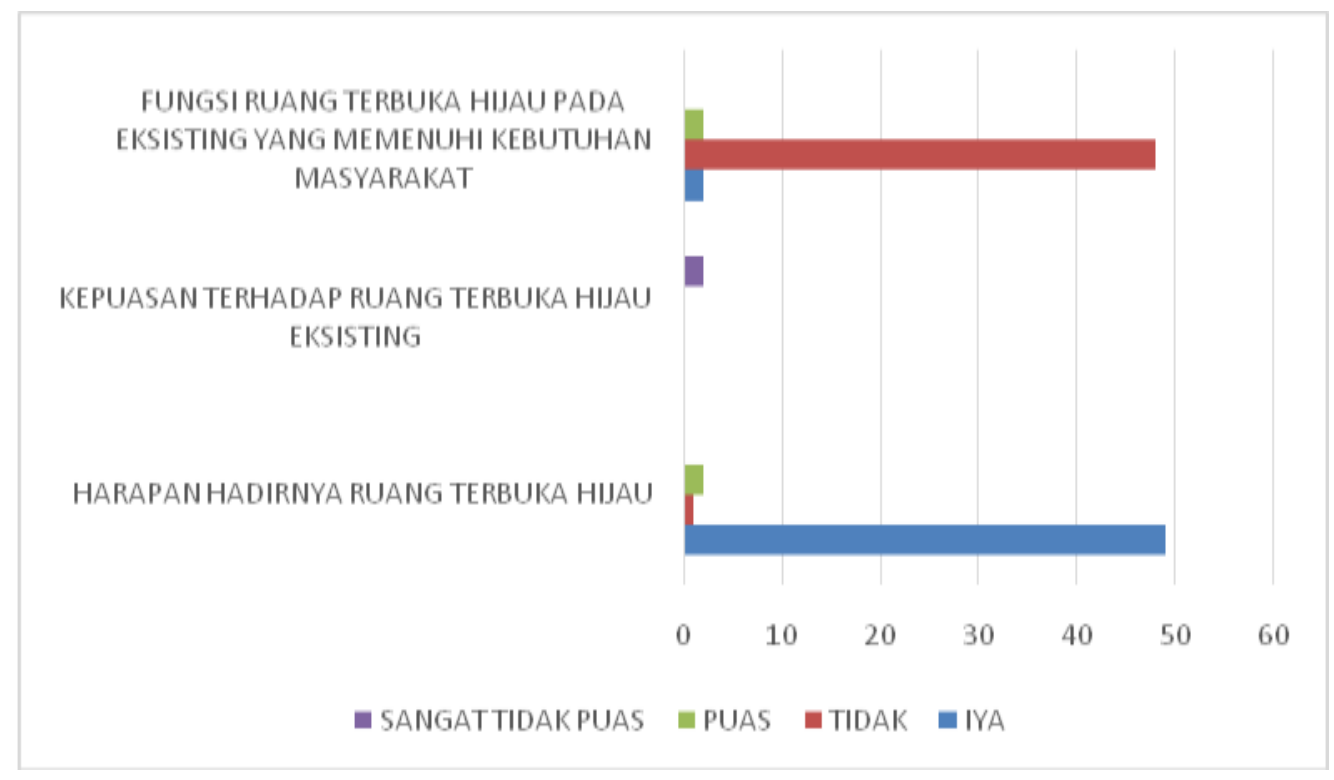

Gambar 3. Grafik Kepuasan Masyarakat terhadap Ruang Terbuka Hijau pada Kondisi Eksisting RW 01

Sumber: Analisis, 2017

\section{Kualitas Ruang Terbuka Hijau}

Berdasarkan hasil wawancara dan kuesioner terhadap kualitas Ruang Terbuka Hijau, $20 \%$ responden menyatakan membutuhkan ruang terbuka hijau dengan kualitas sebagai ruang sosial. Hal ini dibutuhkan untuk mendorong penghuni/masyarakat lingkungan RW untuk bersosialiasi dan lebih aktif dalam kebersamaan yang diwadahi oleh ruang terbuka hijau. Sebanyak 32\% responden membutuhkan ruang terbuka hijau dengan kualitas nilai ekonomi, untuk memberikan peluang bagi pengembangan sumber produk yang bisa dijual seperti hasil kebun maupun tanaman masyarakat dengan jenis bunga, buah, sayur-mayur, makanan, dan lain-lain. Sebanyak $4 \%$ responden menyatakan butuh ruang terbuka hijau dengan kualitas sebagai ruang budaya. Hal ini dibutuhkan sebagai ruang mengekspresikan seni-budaya masyarakat RW 01. Dan terdapat $44 \%$ populasi yang menyatakan bahwa lebih membutuhkan kualitas ruang terbuka hijau yang memiliki nilai terlayaninya penduduk, untuk kenyamanan, keindahan, kelestarian, serta nilai kesehatan bagi masyarakat. Oleh karena itu disimpulkan bahwa masyarakat RW 01 lebih membutuhkan ruang terbuka hijau dengan kualitas terlayaninya penduduk, untuk kenyamanan, keindahan, kelestarian serta kesehatan bagi masyarakat. Kebutuhan berikutnya bagi masyarakat adalah kualitas ekonomi yang mampu menunjang perekonomian masyarakat yang dapat diaplikasikan pada bentuk Ruang Terbuka Hijau 
yang diharapakan. Kemudian kualitas sosial juga diaharapkan ada di dalam sebuah Ruang Terbuka Hijau untuk RW 01. Dengan presentase terendah untuk kebutuhan kualitas dengan nilai budaya, untuk mengekspresikan seni maupun budaya yang ada pada status masyarakat.

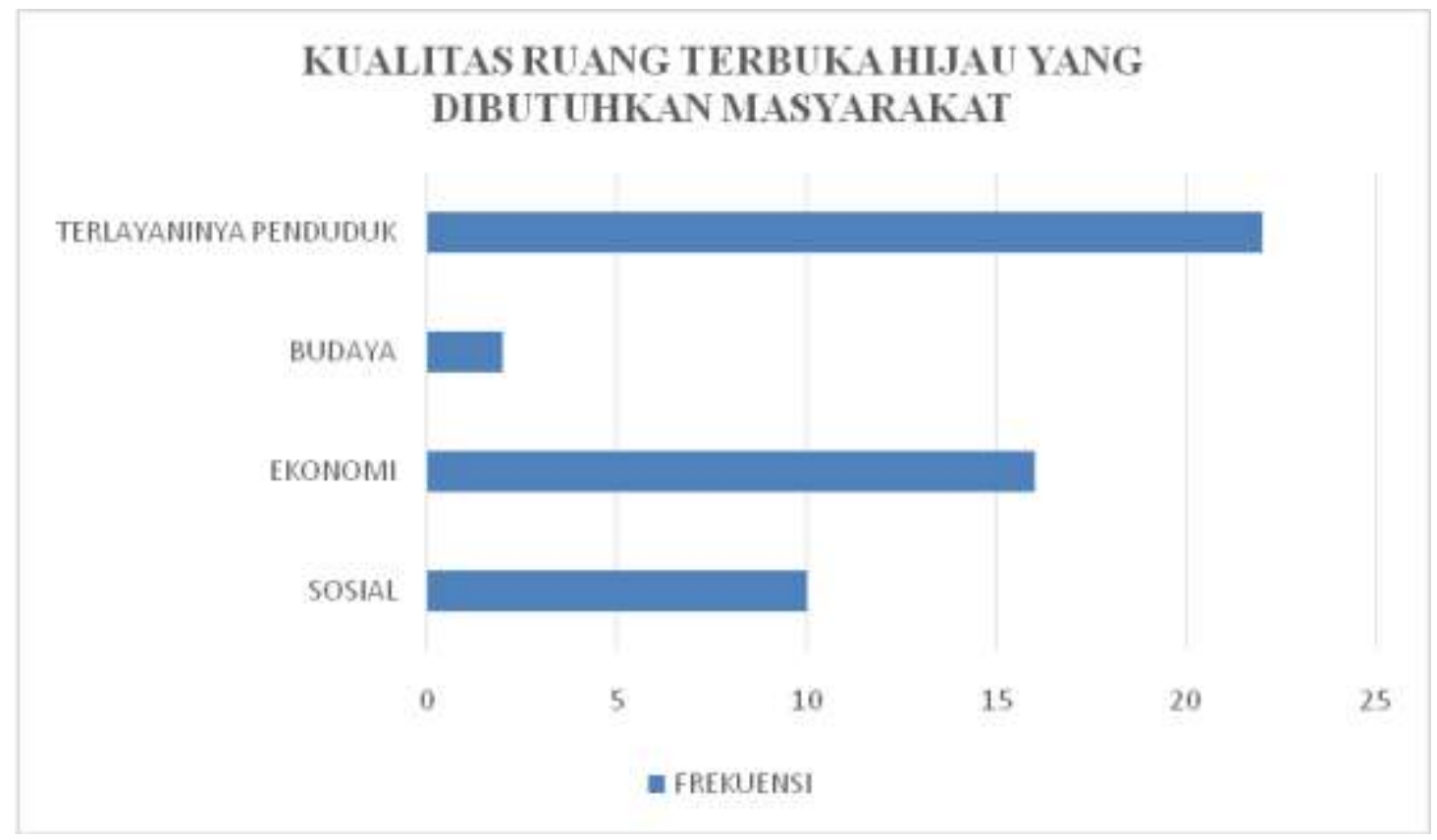

Gambar 4. Grafik Kualitas Ruang Terbuka Hijau yang Dibutuhkan Masyarakat Sumber: Analisis, 2017

\section{Fungsi Ruang Terbuka Hijau}

Berdasarkan pernyataan reponden dalam wawancara dan kuesioner terdapat $2 \%$ responden yang membutuhkan fungsi ruang terbuka hijau sebagai sarana ruang evakuasi untuk keadaan darurat, $4 \%$ responden yang membutuhkan sarana untuk mencerminkan identitas daerah, 6\% responden mementingkan ketersediaan ruang terbuka hijau sebagai sarana untuk memperbaiki iklim mikro kawasan, $8 \%$ responden membutuhkan fungsi ruang terbuka hijau untuk meningkatkan nilai rasa bangga dan meningkatkan nilai daerah, dan $16 \%$ responden membutuhkan fungsi ruang terbuka hijau yang lebih sebagai cadangan oksigen di perkotaan. Hal ini dianggap penting bagi sebagian populasi karena pertumbuhan penduduk akan terus meningkat sehingga kebutuhan oksigen akan semakin bertambah keperluaannya. Sebanyak $22 \%$ responden menyatakan butuh fungsi ruang terbuka hijau yang mampu mewadahi sarana penelitian, pendidikan dan penyuluhan mengingat pentingnya sarana pendidik bagi masyarakat setempat, $24 \%$ responden menyatakan butuh ruang terbuka hijau yang memiliki nilai rekreasi yang aktif maupun pasif. Mayoritas responden, yaitu 52\% responden membutuhkan ruang terbuka hijau yang dapat menghadirkan sarana aktivitas sosial bagi anak-anak, remaja, dewasa dan manula. Oleh karena itu dapat disimpulkan bahwa sebagian besar masyarakat RW 01 membutuhkan ruang terbuka hijau yang memiliki fungsi sebagai sarana aktivitas sosial bagi anak-anak, remaja, dewasa dan manula. Hal ini dianggap penting karena saat ini belum ada ruang terbuka hijau yang mampu menampung seluruh kegiatan masyarakatnya. 


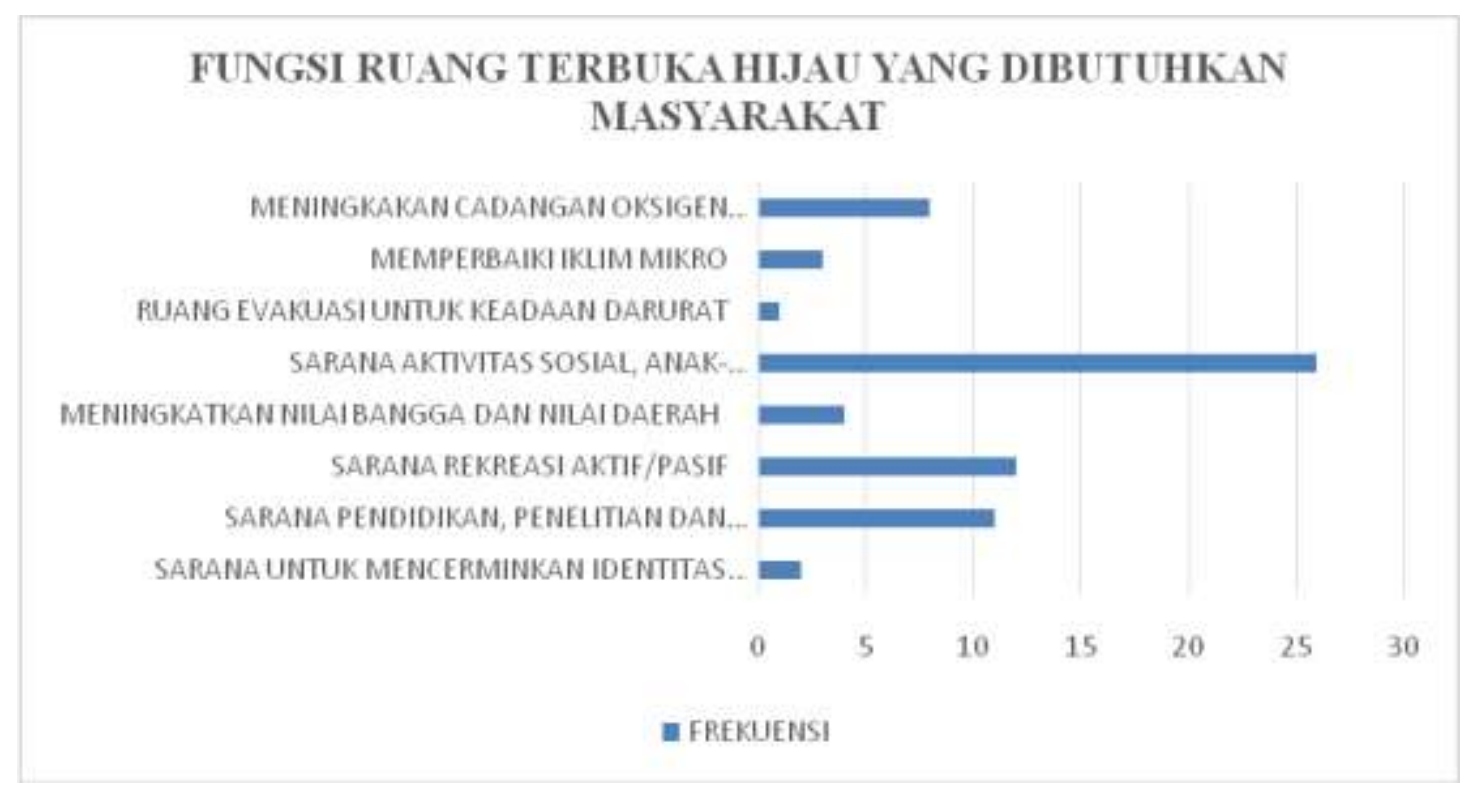

Gambar 5. Grafik Fungsi Ruang Terbuka Hijau yang Dibutuhkan Masyarakat Sumber: Analisis, 2017

\section{E. Jenis Ruang Terbuka Hijau}

Berdasarkan pernyataan masyarakat sebagai reponden dalam wawancara dan kuesioner terdapat $2 \%$ responden yang membutuhkan ruang terbuka hijau dengan jenis hutan kota, ruang terbuka hijau sempadan sungai, ruang terbuka hijau sumber air baku/mata air, dan Ruang Terbuka Hijau pemakaman. Terdapat $6 \%$ responden yang menyatakan bahwa kebutuhan mereka adalah ruang terbuka hijau jalur hijau pejalan kaki yang dapat membuat nyaman pejalan kaki saat melintasi jalur utama pad RW 01. Selanjutnya 8\% responden menyatakan membutuhkan Ruang Terbuka Hijaudengan jenis ruang pejalan kaki, terdapat $12 \%$ responden membutuhkan Ruang Terbuka Hijau taman kota dan $12 \%$ responden juga menyatakan membutuhkan perkebunan. Terdapat juga $26 \%$ persen responden yang menyatakan bahwa membutuhkan ruang terbuka hijau dengan jenis ruang terbuka hijau lapangan olahraga sebagai kebutuhan mereka, mengingat olahraga merupakan sebuah aktivitas untuk fisik dan kesehatan. Mayoritas responden, yaitu $64 \%$ responden menyatakan bahwa masyarakat sebagai responden membutuhkan ruang terbuka hijau dengan jenis taman lingkungan. Taman lingkunan diharapkan dapat memenuhi kebutuhkan masyarakat lingkungan RW 01. Dapat disimpulkan bahwa 64\% responden RW 01 membutuhkan taman lingkungan sebagai kebutuhan ruang terbuka hijau utama bagi masyarakat. Dan 24\% responden membutuhkan lapangan olahraga. Oleh karena itu, kebutuhan masyarakat RW 01 lebih membutuhkan ruang terbuka hijau dengan jenis Taman Lingkungan dan ruang terbuka hijau sebagai lapangan olahraga. 


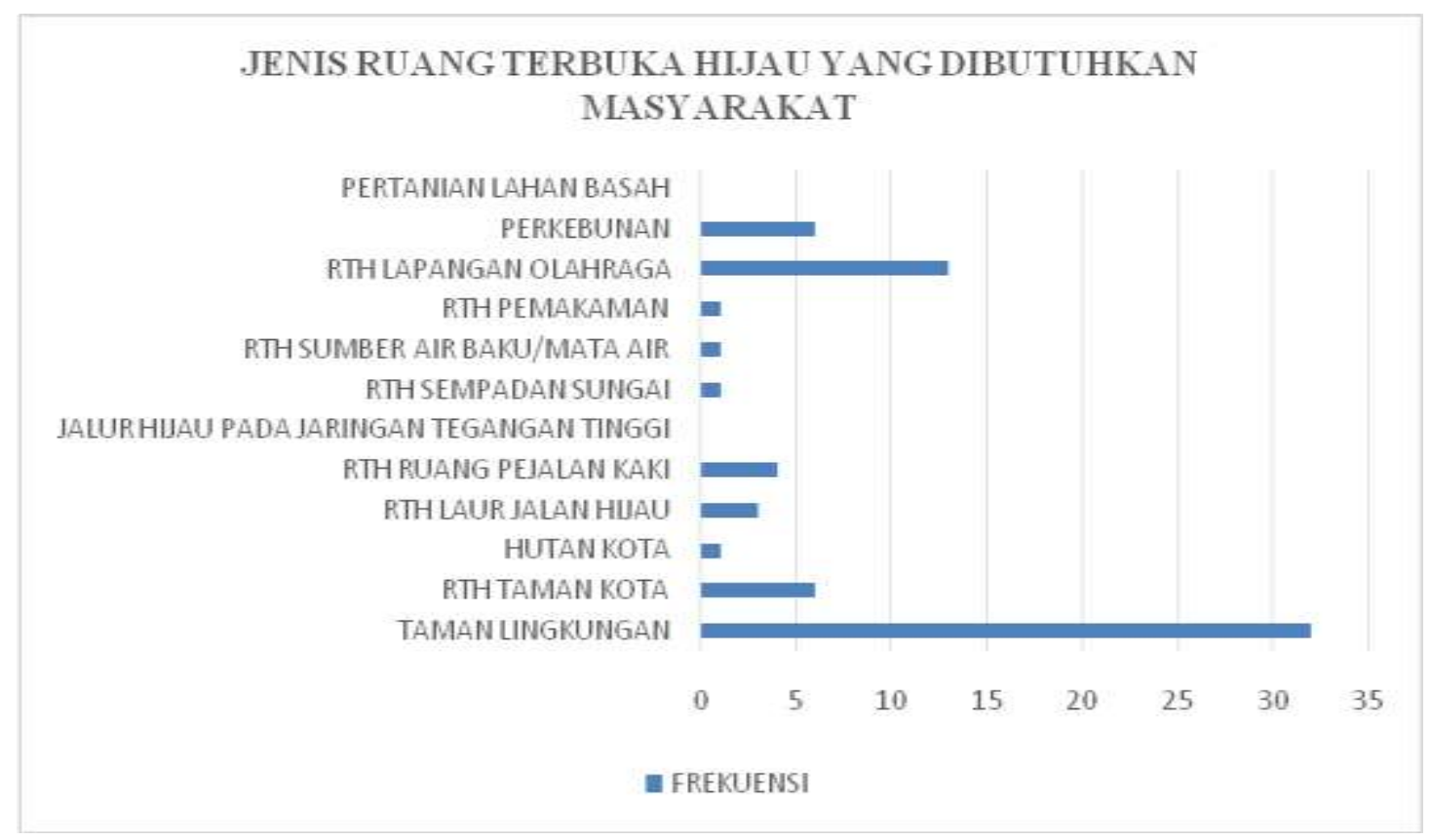

Gambar 6. Grafik Jenis Ruang Terbuka Hijau yang Dibutuhkan Masyarakat Sumber: Analisa, 2017

\section{Analisa Kebutuhan Ruang Terbuka Hijau Berdasarkan Jumlah Penduduk}

Berdasarkan ketentuan yang telah ditetapkan oleh Kementrian Pekerjaan Umum bahwa dalam sebuah taman lingkungan RW dibutuhkan luasan $1250 \mathrm{~m}^{2}$. atau berdasarkan jumlah penduduknya yang saat ini berjumlah 2.146 jiwa, maka dibutuhkan kurang lebih 1073 m2.

Bila merujuk kepada hasil analisis sebelumnya, bahwa masyarakat membutuhkan ruang terbuka hijau dengan fungsi olahraga, maka lapangan olahraga yang cukup dalam luasan tersebut:

1) Lapangan volley dengan luasan $162 \mathrm{~m}^{2}$

2) Lapangan futsal dengan luasan $600 \mathrm{~m}^{2}$

3) Lapangan basket dengan luasan $420 \mathrm{~m}^{2}$

Selain lapangan olahraga adapun komponen-komponen yang harus di penuhi dalam sebuah taman lingkungan untuk Kasawan RW adalah lapangan rumput dan tempat duduk.

\section{Analisa Pemetaan Kebutuhan Ruang Terbuka Hijau}

Pemetaan kebutuhan Ruang Terbuka Hijau dapat diidentifikasi setelah menemukan hasil berdasarkan pernyataan masyarakat dalam wawancara dan kuesioner. Dalam kuesioner dilampirkan peta kawasan RW 01 Kelurahan Paal Lima sebagai penunjuk letak dibutuhkannya Ruang Terbuka Hijau berdasarkan kebutuhan masyarakat. Setelah melalui proses identifikasi didapatkan hasil 18 titik potensi Ruang Terbuka Hijau yang dibutuhkan dan sebagai rekomendasi masyarakat terkait perletakan ruang terbuka hijau.

Adapun letak-letak potensi Ruang Terbuka Hijau yang dibutuhkan menyebar secara acak di dalam kawasan RW 01. Pembagian letak Ruang Terbuka Hijau terbagi menjadi 4 kategori.

Adapun kategori-kategorinya, adalah:

1. Ruang Terbuka Hijau dekat dengan fasilitas umum (fasilitas keagamaan)

2. Ruang Terbuka Hijau dekat/tepian anak sungai

3. Ruang Terbuka Hijau berada di tepian jalan utama, Jl. Husein Hamzah

4. Ruang Terbuka Hijau memanfaatkan lahan fasilitas umum yang tersedia 
Faktor-faktor yang mempengaruhi pemilihan kawasan Ruang Terbuka Hijau adalah masyarakat berharap ruang terbuka hijau dekat dengan fasilitas keagamaan, seperti masjid. Hal ini dikarenakan saat menggunakan fasilitas ruang terbuka hijau masyarakat dapat langsung mengakses fasilitas keagamaan seperti masjid. Kedekatan antara masjid dan ruang terbuka hijau diharapkan mampu untuk mendekatkan masyarakat dan kegiatan keagamaan. Selain itu faktor yang menjadi alasan masyarakat menjadikan ruang terbuka hijau berada di tepian sungai adalah untuk meningkatkan keindahan dan fungsi sungai/anakan Sungai Kapuas sebagai nilai view dan menarik bagi masyarakat. Selain itu sungai/anakan sungai Kapuas juga masih menjadi tempat masyarakat melakukan MCK. Faktor lainnya adalah berada di tepian jalan utama yaitu Jalan Husein Hamzah. Hal ini menjadi rekomendasi masyarakat dengan untuk menjual produk yang masyarakat hasilkan, sehingga ruang terbuka hijau dapat memiliki kualitas ekonomi. Dan faktor lainnya adalah memanfaatkan lahan fasilitas umum yang ada didalam perumahan.

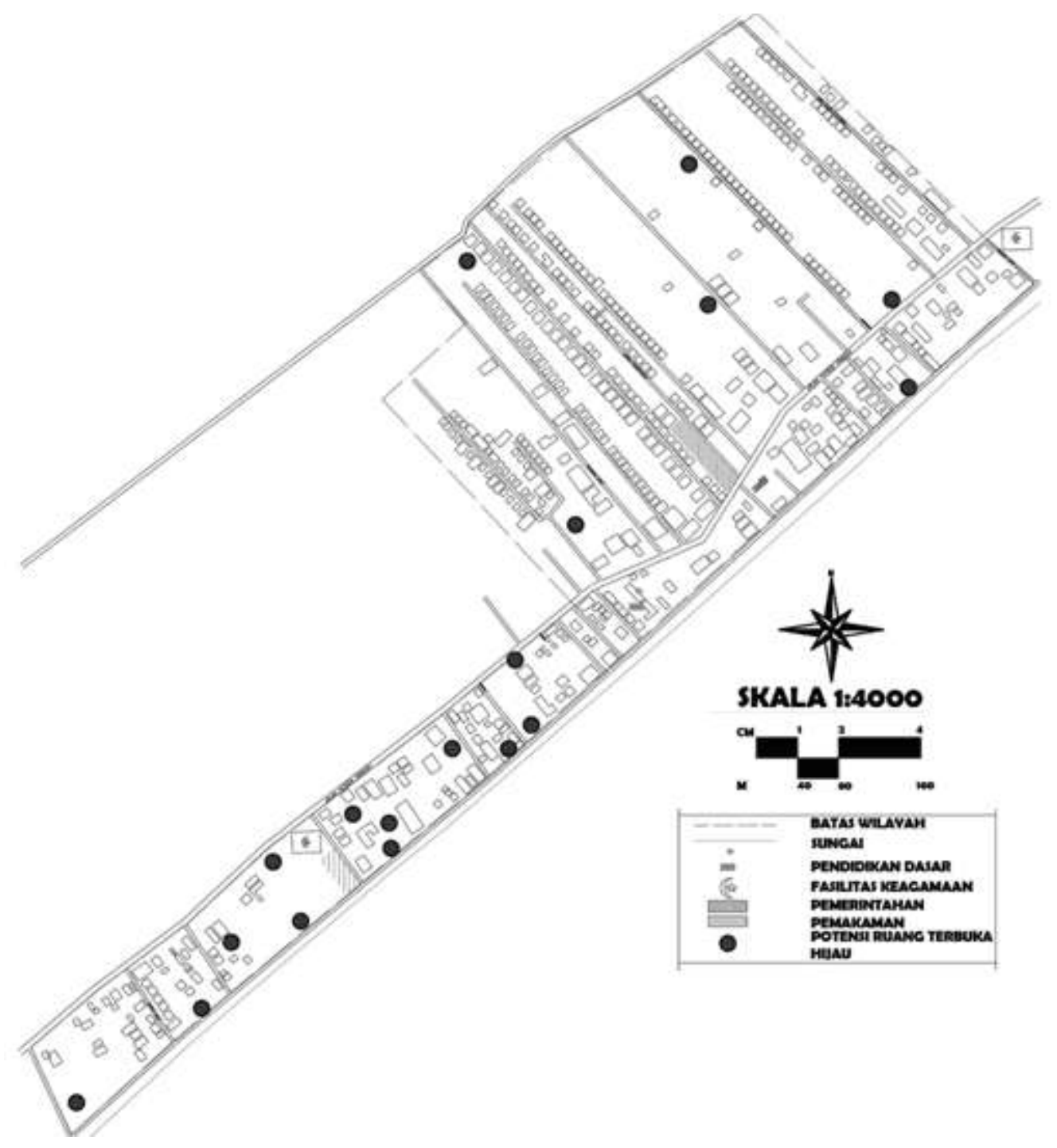

Gambar 7. Hasil Pemetaan Potensi Ruang Terbuka Hijau Pada RW 01 Kelurahan Paal Lima Sumber: Analisa, 2017 


\section{Kesimpulan}

Penelitian ini menghasilkan kesimpulan bahwa saat ini RW 01 Kelurahan Paal Lima tidak atau belum memiliki Ruang Terbuka Hijau yang mampu mendukung segala kebutuhan dan kenyamanan masyarakat. Pada analisa berikutnya menghasilkan pernyataan bahwa masyarakat RW 01 lebih membutuhkan ruang terbuka hijau dengan kualitas terlayaninya penduduk untuk kenyamanan, keindahan, kelestarian serta kesehatan bagi masyarakat. Kualitas ruang terbuka hijau yang mendukung dan memiliki nilai ekonomi menjadi harapan masyarakat disamping yang mampu menunjang perekonomian masyarakat. Kemudian kualitas sosial juga diharapkan ada di dalam sebuah ruang terbuka hijau untuk RW 01.

Sebagian besar masyarakat RW 01 sebagai populasi membutuhkan ruang terbuka hijau yang memiliki fungsi sebagai sarana aktivitas sosial bagi anak-anak, remaja, dewasa dan manula. Adapun bentuk ruang terbuka hijau yang diinginkan adalah taman lingkungan dan lapangan olahraga.

Perletakan potensi Ruang Terbuka Hijau yang dibutuhkan menyebar secara acak di dalam kawasan RW 01. Pembagian letak Ruang Terbuka Hijau terbagi menjadi 4 kategori.Adapun kategori-kategorinya, adalah:

a) Ruang Terbuka Hijau dekat dengan fasilitas umum (fasilitas keagamaan)

b) Ruang Terbuka Hijau dekat/tepian anak sungai

c) Ruang Terbuka Hijau berada ditepian jalan utama, Jl. Husein Hamzah

d) Ruang Terbuka Hijau memanfaatkan lahan fasilitas umum yang tersedia

\section{Daftar Pustaka}

Budi Santoso, R. H. (2012). Pola Pemanfaatan Ruang Terbuka Hijau pada Kawasan Perkampungan Plemburan Tegal, Ngaglik Sleman. INERSIA, Vol. VIII No. 1.

Departemen Dalam Negeri. (2007). Peraturan Menteri Dalam Negeri Nomor 1 Tahun 2007 tentang Penataan Ruang Terbuka Hijau Kawasan Perkotaan. Jakarta: Departemen Dalam Negeri.

Departemen Dalam Negeri Republik Indonesia. (1988). Instruksi Menteri Dalam Negeri No. 14 Tahun 1988 Tentang: Penataan Ruang Terbuka Hijau Di Wilayah Perkotaan . Jakarta: Departemen Dalam Negeri Republik Indonesia.

Direktorat Jenderal Penataan Ruang. (2008). Peraturan Menteri Pekerjaan Umum nomor: 05/PRT/M/2008 tentang Pedoman Penyediaan dan Pemanfaatan Ruang Terbuka Hijau di Kawasan Perkotaan. Jakarta: Departemen Pekerjaan Umum.

Ida Bagos Mantra, K. d. (2012). Penentuan Sampel. Jakarta: LP3ES.

Rushayati, dkk. (2011). Pengembangan Ruang Terbuka Hijau Berdasarkan Distribusi Suhu Permukaan di Kabupaten Bandung. Jurnal Forum Geografi No.25/I/Juli ISSN 08522682 .

Singarimbun, M. (2012). Metode dan Proses Penelitian. Jakarta: LP3ES. 